\title{
UNLOCKING OPPORTUNITIES IN MANUFACTURING OPERATIONS MANAGEMENT SYSTEMS: A PROPOSED FRAMEWORK
}

\author{
C. van der Walt ${ }^{1 *}$, G. Tosen $^{1} \&$ K.K. Govender ${ }^{1}$
}

\section{ARTICLE INFO}

\section{Article details}

Submitted by authors $\quad 30$ Jul 2019

Accepted for publication 14 Feb 2020

Available online 29 May 2020

Contact details

* Corresponding author

nvdwalt@vitalitybroadband.co.za

Author affiliations

1 Da Vinci Institute of Technology Management, South Africa

DOI

http://dx.doi.org/10.7166/31-1-2210

\section{ABSTRACT}

Although manufacturing operations management (MOM) could play an important role in the Fourth Industrial Revolution by making manufacturers more competitive, MOM projects are complex and expensive, and their implementation challenging. The aim of this qualitative research was to establish the engagement requisites to ensure beneficial application of MOM technology. Participants in the study included MOM suppliers and clients with 178-year collective experience. From a thematic analysis, it became evident that a sales approach of selling business benefits, as opposed to technology features, is more suitable for fully exploiting the opportunities and benefits of MOM technology. The communication gap between suppliers and clients also emerged as a probable reason for the failure to embrace MOM technology. One way to address this gap is to focus consciously on enhancing empathy between the role-players. A multi-level engagement structure set up on the client's side could enhance the communication between suppliers and clients, and assist with the consensus buying phenomenon that is manifesting in the contemporary complex sales environment. It became apparent that a framework to engage in the analysis of MOM system opportunities will provide a holistic, integrated, and systemic solution to realising the maximum benefits of MOM technology.

\section{OPSOMMING}

Alhoewel operasionele bestuur in vervaardiging waarskynlik ' $n$ belangrike rol in die vierde industriële rewolusie gaan speel deurdat dit vervaardigers meer mededingend maak, verbloem dit nie die kompleksiteit en koste implikasies nie, en is die daarstelling daarvan dus uitdagend. Die doel van hierdie kwalitatiewe navorsingstuk is om die vereistes vir die voordelige toepassing van operasionele bestuur in vervaardiging te vestig. Deelnemers aan die studie sluit verskaffers en kliënte in met 178 jaar se gesamentlike ervaring. ' $n$ Tematiese analise het getoon dat die bemarkingsbenadering van besigheidsvoordele, eerder as tegnologiese kenmerke, meer geskik is om die volle geleenthede en voordele van operasionele bestuur in vervaardiging te put. Die kommunikasie gaping tussen verskaffers en kliënte het ook na vore gekom as 'n moontlike rede waarom kliënte nie die tegnologie geredelik omhels nie. Een manier om hierdie gaping aan te spreek is om bewustelik die empatie verhouding tussen rolspelers te verbeter. ' $n$ Multivlak betrokkenheid struktuur van die kliënt sal die kommunikasie verbeter en bydra tot die koop-konsensus fenomeen wat in die kontemporêre ingewikkelde verkope omgewing kop uit steek. Dit het tydens die navorsing duidelik geword dat ' $n$ raamwerk vir die ontleding van operasionele bestuur in vervaardiging verskaf ' $n$ holistiese, geïntegreerde en sistemiese oplossing vir die realisering van maksimum voordele.

\section{INTRODUCTION}

The World Economic Forum (WEF) [1] argues that the Fourth Industrial Revolution (4IR) is a digital revolution and a fusion of technologies that are blurring the lines between the physical, digital, and biological. 
According to Lobo [2] (Chief Executive Officer (CEO) of Smart Manufacturing), the 4IR revolves around cyber-physical-systems in the merger of virtual and real worlds, and products, materials, and equipment will have embedded electronics that enable them to communicate with each other. Although manufacturing execution systems (MES) provide a solid foundation for Industry 4.0, they will have to be migrated together with the development of Industry 4.0. According to Siemens [3], manufacturing operations management (MOM) is an evolution of MES. Thus, for this study, these concepts will be used interchangeably.

According to Engineering News [4], the 4IR or Industry 4.0 is now under way, and the South African industry cannot escape it. Industry 4.0 embraces mobile connectivity, Artificial Intelligence (Al), big data, Internet of Things (loT), robotics, 3D printing, wearable technology, and genetic engineering.

Against the backdrop of the unfolding 4IR, Industry 4.0, and the role that MOM technology will play, this study focused on the benefits of MOM technology on the South African manufacturing sector by taking a holistic, integrated, and systemic view in order to realise the maximum benefits of MOM technology and address its manufacturing challenges. Manufacturing companies face unprecedented change in terms of speed, scope, and complexity in the development of the 4IR, and the manufacturing environment is complex by nature. Although MOM provides a solid foundation to leverage the 4IR, there are many challenges. Apriso [5] asserts that in practice IT specialists, as opposed to operations specialists, drive the MOM implementation process, and that a focus on business strategy and stakeholder involvement is necessary. The implementation of a new MOM system is not only about installing and integrating technology to help with production, but also about how the processes are managed and executed, and the cultural challenges that may come from new technology requiring new business practices. Apriso [5] further argues that the early involvement and alignment of management, IT specialists, and operations personnel is essential.

Thus, to ensure the successful and beneficial application of MOM technology, the engagement and analysis requisites need to consider a holistic and systemic way to overcome the challenges of a complex manufacturing and technological environment; the operational, business, and people management challenges; and the unfolding Fourth Industrial Revolution.

Considering the above, the aim of this research was to analyse the pre-requisites for a MOM system opportunity analysis and engagement between MOM technology suppliers and manufacturing clients that would result in the beneficial application of the technology.

\section{MOM OVERVIEW AND CHALLANGES}

According to the Institute of Electrical and Electronic Engineers (IEEE) [6], MOM is used to manage the creation, development, production, and distribution of products, and its functionality includes production management, production performance analysis, and quality management. Syspro [7] asserts that MOM solutions are used to ensure that manufacturing companies remain competitive in today's market, since MOM technology provides for complete manufacturing management and control - including planning, scheduling, tracking, and analysing - to optimise and improve end-to-end manufacturing operations. Syspro [7] adds that the benefits of MOM systems include faster delivery to customers, reducing downtime and bottlenecks, measuring and improving quality, and increasing productivity and output.

Siemens [3] states that MOM technology is a holistic solution that makes manufacturing processes fully visible, allowing for a steady improvement in the performance of manufacturing operations; and the benefits of MOM include optimisation of production performance, improving production efficiency, improving production flexibility, and decreasing time to market. Thus manufacturers with fully digitalised processes are better equipped to respond rapidly to market changes and disruptive innovation. MOM's functionality includes production planning and scheduling, performance management, quality management, asset management, manufacturing intelligence and analytics, genealogy tracking, and inventory management.

Although MOM offers many advantages, there are also many challenges in the successful implementation of the technology. According to research conducted by McKinsey [8], on average IT projects exceed their budget by 45 per cent, their roll-out time exceeds the schedule by seven per cent, and they deliver 56 per cent less value than predicted. Critical Manufacturing [9] lists the following reasons for the failure of MOM projects: no involvement from management, misalignment of technology functionality with business goals, IT driving the project instead of the operations and production department, and requiring the application to model the complex production processes. 
Laudon and Laudon's [10] explanation the reason for the non-involvement of management is that business leaders argue they do not understand IT, and so do not want to get involved. In respect of the misalignment of technology functionality with business goals, Laudon and Laudon [10] found that only 25 per cent of firms achieve such alignment, even though firms that do align are more profitable.

A further consideration, according to Critical Manufacturing [9], is that MOM implementation challenges include the inherently complex nature of the manufacturing environment, since MOM applications are expected to address all aspects of manufacturing operations, with their complex web of components and processes that include materials, machines, and human resources. However, although there may be similarities between manufacturing processes, every process is unique, and data and events occur in real time. Thus the application of MOM technology involves the complex nature of the manufacturing environment, and requires the MOM solution to address every aspect. It is also essential to focus on business objectives, strategies, and value, as opposed to a purely technological focus; and so the terminology needs to be presented to business leaders in a way that they can understand.

\section{RESEARCH METHODOLOGY}

A rigorous qualitative research approach and methodology was followed to collect data from the target population of South African manufacturers, MOM technology providers, and MOM users. The sample included a heterogeneous mix of participants from MOM technology providers and MOM technology users. The sample population consisted of 12 heterogeneous purposive samples, as seen in the table below.

Table 1: Research sample

\begin{tabular}{|l|l|l|}
\hline Participant category & Description & Quantity \\
\hline $\begin{array}{l}\text { MOM technology client } \\
\text { participants }\end{array}$ & $\begin{array}{l}\text { High profile and experienced management and technical staff at } \\
\text { manufacturing companies where MOM technology is used. }\end{array}$ & 66 \\
\hline $\begin{array}{l}\text { MOM technology provider } \\
\text { participants }\end{array}$ & $\begin{array}{l}\text { High profile and experienced management and technical staff at MOM } \\
\text { Technology companies that provide MOM technology and services. }\end{array}$ & 66 \\
\hline
\end{tabular}

\section{RESEARCH APPROACH}

Because this was an exploratory study, semi-structured face-to-face interviews were deemed appropriate to achieve its aim, as recommended by Saunders, Lewis and Thornhill [11]. Semi-structured interviews allowed the researcher to ask probing questions, since an interpretivist philosophy was adopted to uncover why the different actors in a MOM journey made certain decisions. Since the interviews were conducted with mostly senior level staff with busy schedules, interviews were only scheduled for an hour. The interview conversations were electronically recorded.

Express Scribe - a professional audio player software for personal computers (PCs) designed to assist in the transcription of audio recordings [12] - was used to transcribe the recorded conversations.

\section{DATA INTEGRITY AND VALIDITY}

Saunders et al. [11] discuss four qualitative criteria: dependability, credibility, transferability, and authenticity. To ensure the integrity and credibility of the data, the four criteria were used as a guide during the research. Maxwell's [13] seven-point check to combat threats to validity was also followed.

\section{DATA ANALYSIS}

A rigorous five-phase qualitative data analysis process, as articulated by Yin [14], was followed. It consisted of compiling the data into a formal database and disassembling the data in the database by coding, reassembling, interpreting, and concluding.

The first step in the data analysis process was to transcribe the audio recordings of the interviews into text documents. The QDA Miner computerised qualitative data analysis software (Provalis [15]) - an easy-touse package for coding, annotating, retrieving, and analysing small and large collections of documents and images - was used to analyse the transcribed data. Tools used in QDA Miner included coding frequency analysis, word clouds, comments, comments listing, and code retrieval tools. 
The data was collected over a three-month period. Interviews were conducted with six MOM clients and six MOM suppliers in three regions in South Africa. As reflected in Table 2, the primary data consisted of 14 hours of audio recordings that were transcribed into 132000 words. The 12 participants were associated with seven different MOM supplier and client companies, and collectively had a total practical experience with MOM of 178 years. The participants who represented the two groups, the MOM suppliers and the MOM clients, provided a heterogeneous data set.

Table 2: Summary of primary data collection and transcription process

\begin{tabular}{|l|l|l|l|l|l|l|}
\hline $\begin{array}{l}\text { Total } \\
\text { interviews }\end{array}$ & $\begin{array}{l}\text { Interview } \\
\text { period in } \\
\text { months }\end{array}$ & Total regions & $\begin{array}{l}\text { Total audio } \\
\text { recordings in } \\
\text { hours }\end{array}$ & $\begin{array}{l}\text { Total transcribed } \\
\text { words }\end{array}$ & $\begin{array}{l}\text { Total MOM } \\
\text { experience in } \\
\text { years }\end{array}$ & Total companies \\
\hline 12 & 3 & 3 & 14 & 132802 & 178 & 7 \\
\hline
\end{tabular}

The prominent themes that emerged from the data analysis are captured in Figure 1.

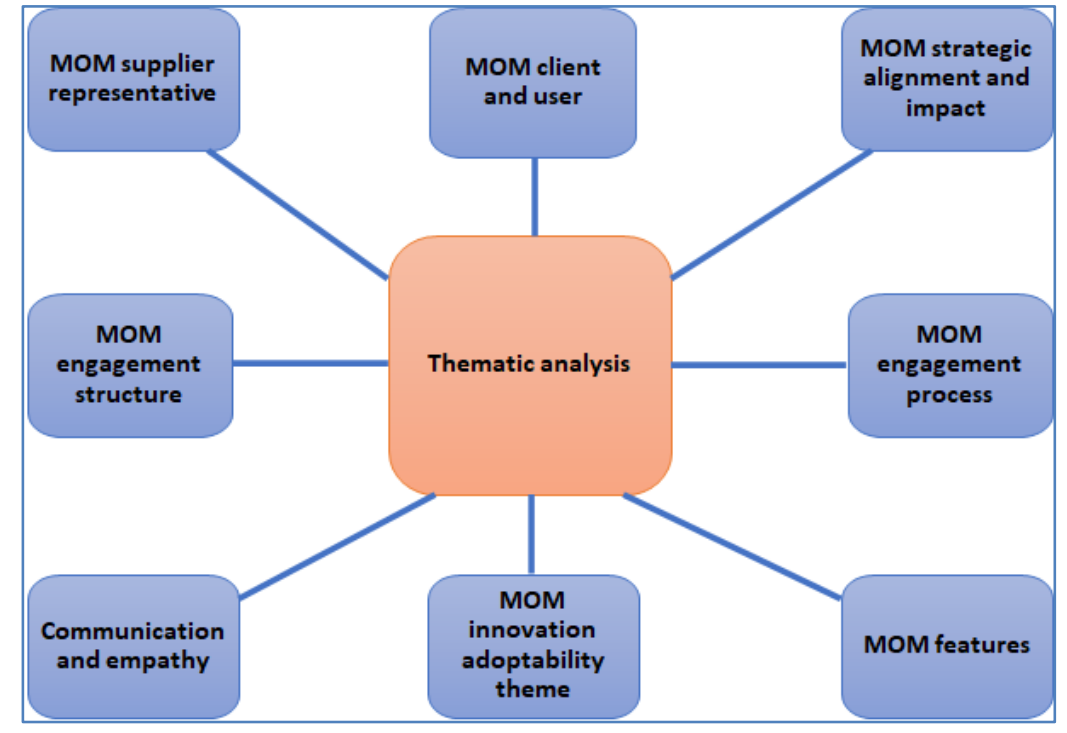

Figure 1: Thematic data analysis

The major themes listed in the figure above, and the major findings that emerged from the research, are briefly discussed below.

\section{MAJOR FINDINGS}

\subsection{MOM supplier representative theme}

During the interviews, the participants were asked to reflect on what they felt were the important attributes of a successful MOM technology supplier representative. The participants echoed the common view that the MOM representative cannot be just another sales person who merely pushes sales, but should be a multi-disciplinary, multi-skilled representative with strong technology and business acumen. It is also important that this person can take control and manage a conversation in a forum such as a MOM workshop.

Practical industry exposure in a manufacturing environment is also important, allowing the representative to bring relevant knowledge to the client on what is happening outside the company or in the industry. The nature of the manufacturing environment, which has unique and complex processes, makes it difficult for outsiders to understand the processes; and so the ability to understand manufacturing processes and perform a requirement analysis is important. Another attribute that emerged strongly during the interviews is that the representative must be trustworthy.

\subsection{MOM client-user theme}

It emerged that one of the main challenges of a MOM opportunity is how to enlist the right people from the client's side, due to the time constraints in the contemporary manufacturing environment. Suggestions from participants to address this challenge included the appointment of a business champion to facilitate 
the engagement process, and to enhance empathy among the plant floor resources to promote greater participation. Another major challenge that emerged is for the client to understand MOM technology, terminology, and business benefits. The MOM representative is therefore required to help to educate the client about MOM technology.

\subsection{MOM strategic alignment and impact theme}

Strategic alignment and impact is the second most prominent code that emerged overall. MOM can align with, and positively influence, basic generic business and competitive strategies, such as a low-cost strategy, a differentiation strategy, driving revenue, or driving profitability. MOM technology does allow for strategies to be operationalised on the shop floor. It is therefore important for the MOM representative to gain an understanding of the company business and competitive strategy as part of the engagement process. For the technology representative to gain an understanding of the general business strategy, they need business acumen, as was evident from the discussion on the MOM supplier representative theme.

\subsection{MOM engagement structure theme}

MOM technology is visible from the top echelons of a company right down to the plant (manufacturing) floor, and so involvement from multiple levels in the organisation is required in a MOM initiative. A theme that emerged is that an engagement structure is needed on the client side, which includes top management all the way down to the operator and users in the plant, and that the engagement structure should accommodate all role players. Apart from the vertical top-to-bottom engagement, horizontal crossfunctional departmental engagement is also required. The engagement team needs to have a shared vision, objectives, understanding, responsibility, and ownership. Gaining consensus is mainly the responsibility of the client. The MOM technology supplier representative must be part of this engagement structure, and can provide a supporting role to reach consensus. The leading and most experienced human resources are needed from the client side to arrive at the best solution. Management and operations bring different perspectives to the forum, and both are needed, since they add value. Management brings a strategic business perspective, and needs to allocate and motivate for resources to participate; operational resources introduce a pragmatic operations perspective.

\subsection{MOM engagement process theme}

The most prominent code that emerged overall from the research was the need for the MOM supplier representatives to understand the needs of the client by understanding the client's business environment and processes. An engagement process needs a significant amount of time, which can easily exceed 12 months. The supplier representative will need to embed and immerse themselves in the operations of the client to gain this understanding.

The engagement process can be described as an exchange of information. The MOM supplier representative needs information on the company's strategy, drivers, and processes, and the clients need information on the MOM technology, features, benefits, and costs. A consultative approach is needed, and the representative needs to bring new insight from the industry to the client, which emphasises the need for the representative to have practical industry exposure. The representative needs to promote the benefits to the business as opposed to merely selling technology and features, and must provide information on alternatives and risk mitigation.

Tools and techniques that can be used include workshops and joint application development (JAD) sessions, plant walk-downs, diagrams and documents, demonstrations, case studies, client site visits, proof of concepts (POCs), and a 'thin slice' approach. Thin slice in this context referring to a single small usable part or function of the bigger system.

\subsection{Communication and empathy theme}

MOM technology suppliers have a deep understanding of MOM and its associated technological terms and acronyms. On the other hand, the client has a deep understanding of their processes and the unique plant 'language' and industry terminology. It is challenging for technology representatives to understand unique production processes and plant- specific language and terminology. It is equally challenging for clients to understand MOM technology, terms, acronyms, functionality, and benefits. This can create a communication gap and a lack of empathy, which are further exacerbated by time pressures and the constraints of the manufacturing clients.

It also emerged from the MOM technology supplier representative side that, although the representative might have had exposure to a similar environment, it is important never to come across as arrogant, as 
knowing it all. It is important for the representative to show interest in the client's business, to show that they are making an effort to understand the client's environment, and to portray a willingness to listen with an open mind to the client's problems. If the representative is knowledgeable and has a lot of experience, this will become apparent later in the process, and this will then be to their benefit. It is important, however, to guard against creating the perception that the representative is there to tell the client how to run their business.

Another suggestion by the participants was to enhance empathy and to highlight the benefit of understanding and appreciating each other's environment. A 'kick-off' meeting to connect first on a social level would benefit the whole process. Participants must be encouraged to ask questions, especially in the beginning. An engagement structure with a shared understanding, involvement, and goals is another important way that emerged to enhance empathy and communication. Power and authority can also be transferred to the client to enhance empathy, especially in the case of information technology (IT) departments, and a MOM champion appointed by the client can further enhance communication and empathy.

\subsection{MOM innovation and adoptability theme}

It emerged that MOM systems are complexl so it is necessary to make the system easy for operators to use, and not to introduce unnecessary complexity. It also emerged that MOM can provide superior functionality over manual and other systems in the MOM domain, but that the technology will not sell itself: a conscious long-term engagement process is required to diffuse MOM in the manufacturing environment. Additional characteristics of MOM that emerged that can positively influence its adoption are flexibility and scalability.

\subsection{MOM features theme}

Although the focus of the study was not on the technical nature of MOM technology, strong features offered by MOM that emerged from the research data included support for the four MOM activities of production, quality, asset, and inventory management. Other prominent MOM features listed by participants included overall equipment effectiveness (OEE) management, genealogy tracking, the provision of plant floor information, and the management of resources.

\section{DISCUSSION OF THE FINDINGS}

Dixon and Adamson [17] note that the 'challenger' approach to sales is a solution-selling one that places a burden on clients and technology providers. Clients expect providers to solve real problems; and to be able to do this, solution providers need to understand the client's underlying problems and challenges. A process that can demand a substantial amount of time from both customers and solution providers is required to craft solutions. Dixon and Adamson [17] further state that solution selling is about asking customers to change their behaviour and to start acting in a new way. As reflected in Table 3, the approach aligns with the required MOM engagement process that emerged from this study.

Table 3: Challenger sales and MOM engagement approaches

\begin{tabular}{|l|l|}
\hline Challenger sales approach & MOM engagement approach \\
\hline $\begin{array}{l}\text { Solve real business problems by } \\
\text { understanding the client's underlying } \\
\text { problems and challenges }\end{array}$ & $\begin{array}{l}\text { The need for the MOM supplier representatives to understand the } \\
\text { needs of the client by understanding their business environment and } \\
\text { processes }\end{array}$ \\
\hline $\begin{array}{l}\text { A process that can demand a substantial } \\
\text { amount of time from both customers and } \\
\text { solution providers is required to craft } \\
\text { solutions }\end{array}$ & $\begin{array}{l}\text { An engagement process that demands significant time can easily } \\
\text { exceed 12 months. The supplier representative will need to embed } \\
\text { and immerse themselves in the operations of the client to gain this } \\
\text { understanding }\end{array}$ \\
\hline $\begin{array}{l}\text { Solution selling is about asking customers to } \\
\text { change their behaviour and to start acting in } \\
\text { a new way }\end{array}$ & Needs to bring new insight from the industry to the client \\
\hline
\end{tabular}

From the alignment summary in Table 3, it can be concluded that the challenger sales approach is a good one to follow with MOM. The supplier representative needs to bring new insight, and the concept from the challenger sales approach, of asking customers to change their behaviour and to start acting in a new way, links to the theme of MOM as an innovation.

According to Rogers [16], the diffusion of innovation consists of four elements: the innovation or new idea, a communication channel, time, and a social system. One of the main problems with the diffusion of innovation, as stated by Rogers [16], is when participants in the communication channel comes with 
different perspectives on the new idea or innovation due to different educational and professional backgrounds. The change agent is often more technologically competent and orientated, the clients more operationally oriented and so does not talk the same language. Unless they have high levels of empathy, more effective communication takes place when participants speak more-or-less the same technical language, ,.

The theory on the diffusion of innovation links to the challenges in the beneficial application of MOM that emerged from the study - that there is a communication gap, and that there is a general lack of empathy between MOM representatives and manufacturing clients. A method that emerged from the study to bridge the communication gap is to focus on enhancing empathy. Other ways of enhancing communication are a multi-level engagement structure and a shared vision, objectives, understanding, responsibility, and ownership of the client's social system.

Rogers [16] adds that the characteristics that can influence the adoptability of an innovation include its complexity, superiority, compatibility, observability, and trialability. As seen from the adoptability and innovation theme that emerged, MOM systems, although complex, do offer superior functionality over manual systems. The superiority in its own is not enough to ensure the successful diffusion of the innovation, and a conscious effort will be required to ensure success. As far as the inherent complexity, systems must be made as easy to use and as user friendly as possible. MOM needs to be compatible with other systems, and to provide the functionality to interface with other systems and equipment. Numerous tools and methods were listed by participants that could influence the trialability and observability of MOM. Its trialability can be enhanced by using a POC and a 'thin slice' approach, and its observability through client site visits, case studies, and demonstrations. Trialability can also help to mitigate risk by allowing the client to see, touch, and feel the technology.

The flexibility and scalability of MOM was also established as an additional characteristic that could positively influence its adoptability in a manufacturing environment. Based on the data analysis and discussion of the key research findings, the engagement framework reflected in Figure 2 is proposed. The framework provides a critical, holistic, and integrated summary of the major themes that emerged from the research, and includes a MOM technology supplier with a multi-skilled, multi-disciplinary MOM representative and a manufacturing client with a multi-level engagement structure. Central to the framework are the engagement process, the time domain and beneficial engagement, strategic alignment and impact, operationalising business and competitive strategy, and operational excellence.

The MOM supplier representative on the left of the proposed framework in Figure 2 needs to be a multiskilled, multi-disciplined resource. The skills include technological and business acumen, industry experience, good domain and manufacturing knowledge, the ability to manage conversations with the client, and the ability to act as a trusted advisor. The supplier representative needs to provide value in the form of knowledge, experience, and insight into solving industry problems. MOM is positioned as an innovation that needs to be diffused into a manufacturing environment; so MOM can be viewed in the light of the diffusion of innovation theory.

To assist in the successful diffusion of MOM into a manufacturing environment, the client's social system needs to be involved and engaged; a multi-level engagement structure can be used for this purpose. It is essential for this multi-level engagement structure (shown on the right-hand side of the framework) for the participants to have a shared vision, objectives, goals, and understanding. Inclusivity results in the participants feeling that they can shape the system to their needs. A top-down vertical involvement is required, spanning all levels in the organisation. Top management involvement is needed to drive the opportunity, allocate resources, and motivate participants. Management brings a business and strategic perspective to the forum, and the operator and user-level engagements are also essential, as these bring a pragmatic operational perspective to the forum. A horizontal cross-functional level engagement is also a pre-requisite to enlist all the needed departmental functions, such as the IT department and operations. 


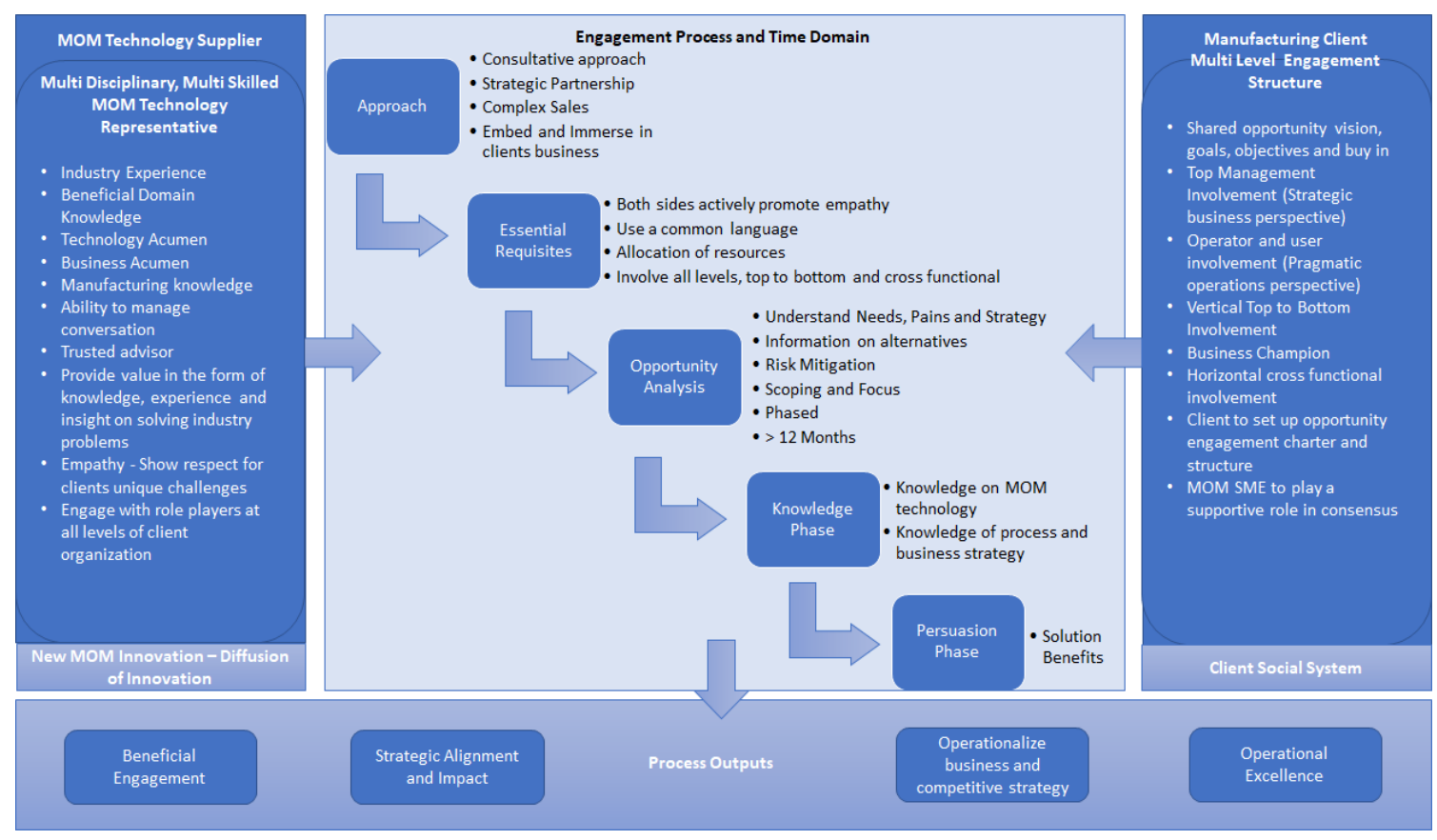

Figure 2: MOM engagement framework

From the research it emerged that it will be very difficult, if not impossible, for the supplier representative to obtain the needed consensus on their own, and that they must rather play a supporting role for the client, who is ultimately responsible for gaining consensus. By providing the multi-level engagement structure, the client can pave the way to reaching consensus by involving all the role players that need to form part of the buy-in of the MOM initiative.

The engagement process and time domain are in the centre of the framework. The engagement process is time-consuming, and can exceed a twelve-month period. It is ultimately responsible for producing the required outputs. A consultative approach is needed, where the emphasis is on solving the needs and challenges of the client. The focus is not on selling a product, but on solving business problems. This approach will require the MOM technology representative to embed and immerse themselves in the business of the client, and to understand the client's problems, as well as the client. New insight must be provided to the client by the technology representative, and the solution will require the client to change their behaviour and to act in innovative ways. The required approach that emerged from the research is in line with the Dixon and Adamson [17] challenger sales approach, and so is a suitable approach to follow as a MOM sales strategy.

Essential prerequisites listed in the engagement process include both sides actively promoting empathy, the need for the client's management to assign resources to the process, and the involvement of all levels in the organisation. A phased approach that provides progressive insight on both sides is to be used. The process includes a knowledge phase consisting of transferring knowledge on MOM technology to the client, and transferring process, business, and strategy information from the business to the supplier representative.

The process output includes beneficial engagement, resulting from the strategic alignment of business and operational strategy with technology, and the operationalisation of business and competitive strategies on the shop floor using the MOM technology. The last output is the operational excellence resulting from MOM functionality, enabling the management of quality, production, inventory, and OEE, and the provision of information.

\section{CONCLUSION}

Although MOM can play a key role in the Fourth Industrial Revolution and allow manufacturers to be more competitive, MOM projects are complex and expensive, and the implementation of MOM technology is challenging. Thus it is recommended that the proposed holistic and systemic MOM opportunity analysis and 
engagement framework be used by MOM technology providers and manufacturing clients during the engagement phase of exploring the application of new MOM initiatives. The purpose of the framework is to ensure the beneficial application of the technology by ensuring that the requisites for success are met:

- $\quad$ the supplier representative is to be multi-skilled,

- a complex solution selling approach - such as the challenger sales approach focusing on enhancing empathy between the role players, and making use of a multi-level engagement structure set up by the client - must be adopted.

The beneficial application of technology can lead to its alignment with the business strategy, leading to a strategic impact, operationalisation of a business and competitive strategy, and operational excellence.

\section{RECOMMENDATIONS}

The exploratory nature of the study provided for a holistic and systemic view of the research problem, and the results from the study were summarised in the form of the MOM opportunity analysis and engagement framework. The framework provides a wider holistic view, and can be used as the starting point for a more in-depth and detailed study of the themes that were uncovered, in order to refine the framework and its various aspects.

One potential area of weakness that was exposed by the participants in the study was the lack of a focus on MOM's financial benefits, and in particular working capital management. The representation of MOM's benefits in a financial model is suggested as an area of further research.

\section{REFERENCES}

[1] WEF. 2016. Fourth industrial revolution. [Online] Available at: https: / /www.weforum.org/agenda/2016/01/the-fourth-industrial-revolution-what-it-means-and-how-torespond/ [Accessed 6 January 2017].

[2] Lobo, F.A. 2016. The evolution of MES systems. [Online] Available at: https://www.smartindustry.com/articles/2016/the-evolution-of-manufacturing-execution-systems/ [Accessed 11 February 2018].

[3] Siemens. 2017. Manufacturing Operations Management. [Online] Available at: https://www.plm.automation.siemens.com/global/en/our-story/glossary/manufacturing-operationsmanagement-mom/13153 [Accessed 6 January 2017].

[4] Engineering News. 2017. The fourth industrial revolution is upon us and South African industry must adapt. [Online] Available at http://www.engineeringnews.co.za/article/the-fourth-industrial-revolution-is-upon-us-and-southafrican-industry-must-adapt-2017-10-27 [Accessed 11 February 2018].

[5] Apriso. 2015. Fixing manufacturing IT project failures. [Online] Available at: http://www.apriso.com/blog/2015/06/fixing-manufacturing-it-project-failures/ [Accessed 10 February 2018].

[6] IEEE. 2018. Manufacturing operations management software. [Online] Available at: http://www.globalspec.com/learnmore/industrial_engineering_software/enterprise_plant_management_softwar e/manufacturing_operations_management_software_mom [Accessed 6 January 2018].

[7] Syspro. 2017. Manufacturing operations management. [Online] Available at: https://za.syspro.com/dl/FS/SYSPRO-Manufacturing-Operations-Management-ALL-FS.pdf [Accessed 6 January 2017].

[8] McKinsey. 2012. Delivering large-scale IT projects on time, on budget and on value. [Online] Available at: https://www.mckinsey.com/business-functions/digital-mckinsey/our-insights/delivering-largescale-it-projects-on-time-on-budget-and-on-value [Accessed 10 February 2018].

[9] Critical Manufacturing. 2013. 10 reasons why so many MES projects fail. [Online] Available at: http://www.criticalmanufacturing.com/en/newsroom/blog/posts/blog/why-mes-projects-fail-43\#.V1zuC490JPY [Accessed 10 February 2018].

[10] Laudon, K.C. \& Laudon, J.P. 2012. Management information systems (12th edition). Harlow: Pearson.

[11] Saunders, M., Lewis, P. \& Thornhill, A. 2016. Research methods for business students (7th edition). Harlow: Pearson.

[12] NHC Software. 2015. Express scribe transcription software. [Online] Available at: http://www.nch.com.au/scribe/index.html [Accessed 5 August 2016].

[13] Maxwell, J.A. 2009. Designing a qualitative study (2nd edition). Thousand Oaks: SAGE Publications.

[14] Yin, R.K. 2011. Qualitative research from start to finish. New York: Guilford Press.

[15] Provalis Research. 2016. Qualitative data analysis software. [Online] Available at: http://provalisresearch.com/products/qualitative-data-analysis-software/ [Accessed 5 August 2016].

[16] Rogers, E.M. 2003. Diffusion of innovation (5th edition). New York: The Free Press.

[17] Dixon, M. \& Adamson, B. 2013. The challenger sale. London: Penguin. 